\title{
PECOSA-BAER: A NEW CULTIVAR OF WHITE LUPIN WITH DETERMINED BUSHY GROWTH HABIT, SWEET GRAIN AND HIGH PROTEIN CONTENT
}

\author{
Erik von Baer ${ }^{1 *}$, Ingrid von Baer ${ }^{1}$, and Ricardo Riegel ${ }^{2}$
}

\begin{abstract}
The expansion of white lupin (Lupinus albus L.) cultivation in Chile is subject to the availability of cultivars presenting high yield potential, tolerance to the main fungal diseases and homogeneous ripening. In response to these requirements, a new cultivar has been developed and registered as 'Liapec-1', commercially registered as 'Pecosa-Baer'. This new cultivar has determined bushy growth habit. Its flowering period is concentrated in approximately 40 days, less than the 77 days of cv. Rumbo-Baer. This trait allows it to reach harvest without heterogeneity problems. The seed is speckled, flat and medium-sized (370 g/1000 grains aprox.). The kernels are sweet and have a high protein content of around $41 \%$ (dry matter basis). In field assays, 'Pecosa-Baer' presents a good tolerance to diseases caused by Colletotrichum lupini and Pleiochaeta setosa. The new cultivar has outstanding stability and yield levels, even under low fertilization conditions. An average yield of $5.43 \mathrm{t} \mathrm{ha}^{-1}$ was obtained over four seasons in two locations. In order to maximize its yield, 'Pecosa-Baer' must be sown between April and June at a rate of 140-160 $\mathrm{kg} \mathrm{ha}^{-1}$. Given the high protein content and low alkaloid levels of the seeds, they can be included in the diet of all types of animals.
\end{abstract}

Key words: Lupinus albus, cultivar, Colletotrichum, Pleiochaeta.

\section{INTRODUCTION}

With an area under cultivation of 22500 ha and an estimated production of $51400 \mathrm{t}$ in 2007 , Chile has become the third largest producer of lupin grain, after Australia and Germany (FAOSTAT, 2008). While Australia bases its production almost exclusively on the species Lupinus angustifolius L., the most cultivated species in Chile is white lupin (Lupinus albus L.). The seeds of Lupinus albus have higher protein and oil content than those of L. angustifolius (Cowling et al., 1998). As well as fixing nitrogen in acidic soils, the white lupin is capable of drawing upon phosphorous that is not available for other legumes (Braum and Helmke, 1995).

The breeding program of the company Semillas Baer has a long tradition of developing white lupin cultivars adapted to the environmental conditions of southern Chile. Some milestones have been registered in the

${ }^{1}$ Seeds Baer, Casilla 87, Temuco, Chile. "Corresponding author (infoseedsbaer@semillasbaer.cl).

${ }^{2}$ Universidad Austral de Chile, Facultad de Ciencias Agrarias, Casilla 567, Valdivia, Chile.

Received: 04 September 2008.

Accepted: 04 January 2009.
Servicio Agrícola y Ganadero (SAG) the cvs. VictoriaBaer (1989), Rumbo-Baer (1995) and Typ Top-Baer (1999). The expansion of the cultivation of lupin is subjected to the availability of cultivars that present high potentials of yield, tolerance to the main fungal diseases and homogeneous ripening. Responding to these requirements, a new cultivar has been developed that has a determined bushy growth habit, shows good tolerance to Colletotrichum lupini and Pleiochaeta setosa, and yields a sweet grain with high protein content.

\section{Origin}

The cv. Pecosa-Baer was obtained by masal selection and subsequent selection of a single plant based on a compound crossing between the cv. Typ Top-Baer and a genotype from the crossing by Semillas Baer of the cv. Rumbo-Baer and a wild accession from the Azores Islands, Portugal. The pedigree code is 9608-B-04 3CJ and it is registered under the name Liapec-1 in the SAG.

\section{Agronomic characteristics and quality parameters}

Cultivar Pecosa-Baer presents a determined bushy growth habit, with a plant height between 75 to $80 \mathrm{~cm}$. Its low height and structure allows for few problems of lodging, threshing or shattering. 
The average thermal time (base $4{ }^{\circ} \mathrm{C}$ ) required to initiate its flowering is $632^{\circ} \mathrm{C}$. Seeded in Cajón (38 $48^{\circ}$ ' S, $72^{\circ} 29^{\prime}$ W), La Araucanía Region in April, this cultivar began flowering 177 to 180 days after seeding. This is 16 to 18 days later than flowering in Typ Top-Baer. Flowering in Pecosa-Baer lasts an average of $315^{\circ} \mathrm{C}$, notably more concentrated than in the indeterminate cv. Rumbo-Baer, in which flowering lasts on average $660{ }^{\circ} \mathrm{C}$ (Table 1). At harvest the cv. Typ Top-Baer is more precocious than Pecosa-Baer and the latter is in turn more precocious and with more homogeneous ripening than Rumbo-Baer.

The name Pecosa (Freckles) derives from the characteristic speckled coloring of its grains. This character comes from the wild accession from the Azores Islands. The grains of Pecosa-Baer are flat and mediumsized, similar to Rumbo-Baer, with a 1000 -grain weight of $370 \mathrm{~g}$. Its protein content of around $41 \%$ (dry matter basis) and oil content of around 12\% (ether extract) are higher than those of the cv. Rumbo-Baer. As well, the new cultivar has sweet grains that are apt for direct human consumption given that the alkaloid content is below the tolerable level of $0.02 \%$ (Table 1, Cowling et al., 1998).

\section{Response to diseases}

In the assays carried out to date Pecosa-Baer has been notable for its tolerance to anthracnosis (Colletotrichum lupini), the main fungal disease that affects L. albus in Chile and in the world (Mera and Galdames, 2007; Nirenberg et al., 2002). Its tolerance to this phytopathogen was higher than that of the two cultivars to which it was being compared (Table 1).

This new variety is moderately tolerant to the disease brown spot (Pleiochaeta setosa), with infestation levels similar to those of Rumbo-Baer.

\section{Grain yield}

Pecosa-Baer was evaluated in yield assays with a random block design with four replications, on plots of $5 \mathrm{~m}^{2}$ in the areas of Cajón (pH 5.6) and Gorbea (39 ${ }^{\circ}$ ' S, 72² ' W; pH 4.5), La Araucanía Region. Minimal fertilization was employed, equivalent to $300 \mathrm{~kg} \mathrm{ha}^{-1}$ $\mathrm{CaSO}_{4}$, without fertilizers that contributed NPK nutrients. The equivalent to $120 \mathrm{~kg} \mathrm{ha}^{-1}$ of seeds were sown after

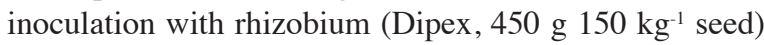
and treated with the fungicides, carboxin and thiram

Table 1. Agronomic characteristics, grain quality parameters and disease behaviour of lupin cvs. Pecosa-Baer, Typ TopBaer and Rumbo-Baer.

\begin{tabular}{|c|c|c|c|}
\hline \multirow[b]{2}{*}{ Parameters $^{1}$} & \multicolumn{3}{|c|}{ Cultivars } \\
\hline & Pecosa-Baer & Typ Top-Baer & Rumbo-Baer \\
\hline \multicolumn{4}{|l|}{ Agronomic characteristic } \\
\hline Growth habits & Determined bushy growth & Determined without branching & Undetermined \\
\hline Height, $\mathrm{cm}$ & $75-80$ & $50-60$ & $80-90$ \\
\hline Lodging, $\%$ & 0 & 0 & $0-30$ \\
\hline Shattering & Not present & Not present & Not present \\
\hline Beginnning of flowering, ${ }^{\circ} \mathrm{C}$ & $612-652$ & $496-557$ & $488-564$ \\
\hline End of flowering, ${ }^{\circ} \mathrm{C}^{2}$ & $926-971$ & $780-833$ & $1133-1240$ \\
\hline Grain color & $\begin{array}{c}\text { Speckled, white background } \\
\text { with brown spots }\end{array}$ & White & White \\
\hline Weight of 1000 grains, $\mathrm{g}$ & $363-370$ & $388-412$ & $362-384$ \\
\hline \multicolumn{4}{|l|}{ Quality parameters } \\
\hline Protein, $\%^{3}$ & $40-42$ & $38-40$ & $37-38$ \\
\hline Alkaloids in the grains, $\%^{4}$ & $<0.02$ & $<0.03$ & $<0.05$ \\
\hline \multicolumn{4}{|l|}{ Disease behavior ${ }^{5}$} \\
\hline Pleiochaeta setosa & 3 & 4 & $3-4$ \\
\hline Colletotrichum lupini & $1-2$ & $2-4$ & $2-3$ \\
\hline
\end{tabular}

'Ranges obtained in eight observations during the 2004-2005 and 2005-2006 seasons at the El Hualle Farm of CAMPEX Semillas Baer in Cajón, La Araucanía Region.

${ }^{2}$ Thermal time to full flowering: Sum of heating degree days (base $4{ }^{\circ} \mathrm{C}$ ) from seeding.

${ }^{3}$ Indirect method through near infrared, dry matter basis.

${ }^{4}$ Determination of volumetric alkaloids by solvent extraction.

${ }^{5}$ Scale used: 1 = without symptoms; 9 = complete destruction. 
Table 2. Yield of lupin cvs. Pecosa-Baer, Typ Top-Baer, and Rumbo-Baer in the years and locations indicated.

\begin{tabular}{lcc}
\hline & \multicolumn{2}{c}{ Locations } \\
\cline { 2 - 3 } Cultivars & Cajón $^{1}$ & Gorbea $^{2}$ \\
\cline { 2 - 3 } 2004-2005 & & \\
Pecosa-Baer & $5.72 \mathrm{~b}$ & $5.93 \mathrm{~b}$ \\
Typ Top-Baer & $2.55 \mathrm{c}$ & $3.35 \mathrm{c}$ \\
Rumbo-Baer & $6.64 \mathrm{a}$ & $9.33 \mathrm{a}$ \\
2005-2006 & & \\
Pecosa-Baer & $4.75 \mathrm{~b}$ & ni \\
Typ Top-Baer & $2.75 \mathrm{c}$ & ni \\
Rumbo-Baer & $6.75 \mathrm{a}$ & \\
2006-2007 & & $6.45 \mathrm{a}$ \\
Pecosa-Baer & $6.80 \mathrm{a}$ & $3.43 \mathrm{c}$ \\
Typ Top-Baer & $4.80 \mathrm{~b}$ & $4.83 \mathrm{~b}$ \\
Rumbo-Baer & $6.85 \mathrm{a}$ & \\
2007-2008 & & $6.23 \mathrm{~b}$ \\
Pecosa-Baer & $2.10 \mathrm{~b}$ & $8.60 \mathrm{a}$ \\
Rumbo-Baer & $4.68 \mathrm{a}$ & \\
\hline
\end{tabular}

'CAMPEX Semillas Baer, El Hualle, Cajón (3840' S, 72²9' W), La Araucanía Region.

${ }^{2}$ CAMPEX Semillas Baer, El Encanto, Gorbea (396' S, 7241' W), La Araucanía Region.

Different letters in each season and location indicate differences according to the Duncan test $(\mathrm{p}<0.05)$.

ni: no information.

(Vitavax Flo, BASF Chile, $250 \mathrm{~cm}^{3} 100 \mathrm{~kg}^{-1}$ seeds), as well as the insecticide clorpirifos (Master, Arysta, $250 \mathrm{~cm}^{3}$ $100 \mathrm{~kg}^{-1}$ seeds). The seeding distance was $0.2 \mathrm{~m}$ between rows. Simazine (Gesatop $90 \mathrm{WG}$ Syngenta, $1.5 \mathrm{~kg} \mathrm{ha}^{-1}$ ) was applied at seeding for weed control.

In the two locations and during the four seasons studied, Pecosa-Baer presented higher yields than those of Typ Top-Baer and somewhat lower than those of RumboBaer (Table 2). It should be considered that the assays were established with the same seed doses, which puts cultivars with a determined growth (Typ Top-Baer and Pecosa-Baer) at a disadvantage in comparison to those that present a higher number of branches and flowerings, such as Rumbo-Baer. The lower grain yield of PecosaBaer was compensated by its higher protein content. Its average yield, considering all the evaluated assays, was $5.43 \mathrm{tha}^{-1}$. Considering average protein levels of de $41 \%$ (dry matter basis base), this cultivar produces $1.93 \mathrm{tha}^{-1}$ of protein. Considering the low levels of fertilizer used and the fitosanitary management, the stability of the PecosaBaer yields are notably, exceeding $4.75 \mathrm{t} \mathrm{ha}^{-1}$ of grain in all the assays, except in the extreme drought 2007-2008 season.
Table 3. Yield ( $\mathrm{t} \mathrm{ha}^{-1}$ ) of lupin cv. Pecosa-Baer in relation to plant density.

\begin{tabular}{ccc}
\hline Seed doses & Plant density & Yield \\
\hline $\mathrm{kg} \mathrm{ha}^{-1}$ & plants $\mathrm{m}^{2}$ & $\mathrm{t} \mathrm{ha}^{-1}$ \\
80 & 19.9 & $4.28 \mathrm{c}$ \\
100 & 24.3 & $4.98 \mathrm{bc}$ \\
120 & 30.8 & $5.30 \mathrm{~b}$ \\
140 & 35.2 & $6.28 \mathrm{a}$ \\
160 & 38.9 & $6.30 \mathrm{a}$
\end{tabular}

Different letters indicate differences according to the Duncan test $(\mathrm{p}<$ $0.05)$.

\section{Cultivation area, seeding time and seed doses}

This cultivar is adapted to the Bío-Bío and La Araucanía Regions. Nevertheless, its precocity allows for seeding as far south as Osorno in the Lake Region. To obtain high yields, it is recommended to seed in the months of April to June, with seed doses of 140 to $160 \mathrm{~kg} \mathrm{ha}^{-1}$. A seed dose of $120 \mathrm{~kg} \mathrm{ha}^{-1}$ or less results in decreased yields (Table 3).

\section{Uses}

Its high protein content and low alkaloid levels allow for its use in balanced diets for humans and for fish farming, monogastric and ruminant species.

\section{RESUMEN}

Pecosa-Baer: Nuevo cultivar de lupino blanco de hábito de crecimiento determinado arbustivo, grano dulce y alto contenido de proteína. La expansión del cultivo del lupino blanco (Lupinus albus L.) en Chile está sujeta a la disponibilidad de cultivares que presenten altos potenciales de rendimiento, tolerancia a las principales enfermedades fungosas y una maduración homogénea. Respondiendo a estos requerimientos se ha desarrollado el nuevo cultivar inscrito como 'Liapec-1' y registrado comercialmente como 'Pecosa-Baer'. Este nuevo cultivar presenta un hábito de crecimiento determinado arbustivo. Su floración se concentra en aproximadamente 40 días, muy por debajo de los 77 días del cv. Rumbo-Baer. Esta característica le permite llegar a cosecha sin problemas de heterogeneidad de madurez. Su grano es de color jaspeado, forma aplanada, dulce, de tamaño medio (aprox. $370 \mathrm{~g} / 1000$ granos) y con un alto contenido de proteína que bordea el $41 \%$ (base materia seca). En ensayos de campo 'Pecosa-Baer' presenta una buena tolerancia a las enfermedades causadas por Colletotrichum lupini y Pleiochaeta setosa. Se debe destacar la estabilidad y niveles de rendimiento de este nuevo cultivar, aún bajo condiciones de baja fertilización. En cuatro temporadas, en dos localidades se obtuvo un rendimiento promedio 
de 5,43 $\mathrm{t} \mathrm{ha}^{-1}$. Para maximizar su rendimiento, 'PecosaBaer' debe ser sembrada entre abril y junio con una dosis de semilla de entre 140 y $160 \mathrm{~kg} \mathrm{ha}^{-1}$. Su alto contenido proteico y bajos niveles de alcaloides en los granos permiten su inclusión en la dieta de todo tipo de animales.

Palabras clave: Lupinus albus, cultivar, Colletotrichum, Pleiochaeta.

\section{LITERATURE CITED}

Braum, S.M., and P.A. Helmke. 1995. White lupin utilizes soil phosphorus that is unavailable to soybean. Plant Soil 176:95-100.

Cowling, W.A., B.J. Buirchell, and M.E. Tapia. 1998. Lupin. Lupinus L. Promoting the conservation and use of underutilized and neglected crops. $105 \mathrm{p}$. Institute of Plant Genetics and Crop Plant Research, Gatersleben/International Plant Genetic Resources Institute, Rome, Italy.
FAOSTAT. 2008. FAOSTAT Agriculture Data. FAO, Rome, Italy. Available at http://faostat.fao.org (accessed 3 September 2008).

Mera, M., y R. Galdames. 2007. Boroa-INIA, primera variedad de lupino (Lupinus albus) amargo exportable obtenida en Chile. Agric. Téc. (Chile) 67:320-324 .

Nirenberg, H.I., U. Feiler, and G. Hagedorn. 2002. Description of Colletotrichum lupini comb. nov. in modern terms. Mycologia 94:307-320. 